\title{
Evaluating the natural regeneration of lowland bamboo (Oxytenanthera abyssinica A. R. Munro) forests after mass flowering and mass death in Homosha District of Benishangul Gumuz Region, North Western Ethiopia
}

\begin{abstract}
This study was done to assess the regeneration status of lowland bamboo after gregarious flowering and death in Benishangul Gumuz Region, Homosha District, Jimma and Sherkole Kebeles, North west of Ethiopia. A systematic sampling technique was used to survey lowland bamboo. A total of 20 and 11 sample plots were surveyed in Jima and Sherkole Kebeles respectively and each plots with $10 \times 10 \mathrm{~m}$ size. Field observation, regeneration inventory, FGDs, and questionnaire survey on 80 households were used to collect data. Descriptive and inferential statistics were used for data analysis. The seedlings and culms had a significant difference (One way ANOVA p $<0.05)$ in density, size (DBH) and height between the two sites. However, the size difference was statistically insignificant. Height and diameter classes distribution indicated highest number of individuals in the lower classes $(<1 \& 1-2$ year $)$ and this suggests that the age of the forest after mass flowering and death is not more than 4 to 5 years hence regeneration could be sensitive to the anthropogenic disturbances. Sampled HHs harvest bamboo at an age of $<1 \& \geq 3$ years and harvesting intensity was observed to be related with culms size rather than age class across different management.
\end{abstract}

Keywords: anthropogenic, harvesting, lowland bamboo, management, regeneration
Volume 4 Issue I - 2019

\section{Dereje Mosissa,' Gebremedihin Woldegebriel ${ }^{2}$ \\ 'Ethiopian Biodiversity Institute, Assosa Biodiversity Center, Forest and Rangeland Biodiversity Case team, Ethiopia ${ }^{2}$ Benishangul Gumuz regional, State Bureau of Environment Forest and Land administration, Ethiopia}

Correspondence: Dereje Mosissa, Ethiopian Biodiversity Institute, Assosa Biodiversity Center, Forest and Rangeland Biodiversity Case team, Ethiopia, Tel +25I (0)949045964, Email derament5964@gmail.com

Received: January 03, 2019 | Published: February 12, 2019
Abbreviations: BGR, Benishangul Gumuz Regionl; BGNRS, Benishangul Gumuz National Regional State; BGRBOA, Benishangul Gumuz Region Bureau of Agriculture; BGRFSSR, Benishangul-Gumuz Regional food security strategy report; BOFED, bureau of finance and economy development; BOIPPCSA, bureau of information and public participation co-ordination and social affairs; CBOs, community based organizations; CSA, central statistics agency of Ethiopia; HHH, house hold heads; HWAO, Homosha woreda agricultural office; LLB, lowland bamboo; WBISPP, woody biomass inventory and strategic planning project; INBAR, International network for bamboo and rattan; NTFPs, non-timber forest products; $\mathrm{DBH}$, diameter at breast height; FAO, food and agricultural organization; NGOs, Non-Governmental organizations; HWAO, Homosha woreda agricultural office

\section{Introduction}

Bamboo is a natural regenerative plant which naturally grows mostly in the forest as a bushy grass in tropical and subtropical ecology. It is also naturally found as an understory plant, which can also grow in moist regions and can be referred to as woody grass and classified into species ranging in number from 1439 to 1500 with 115 genera's across the globe, ${ }^{1}$ the bamboo plant plays a significant role in the preservation of the forest as it releases about $35 \%$ more oxygen into the atmosphere than other plants, thus reducing atmospheric carbon dioxide as compared to hard and softwood.

As many as 1500 bamboo species exist worldwide, most of which grow in Southeast Asia. Africa has a total of only 1.4 million hectares of bamboo, much of which is distributed over Eastern Africa. ${ }^{2}$ As some literatures indicates the pure natural bamboo forest in Ethiopia was the largest in Africa, over about 1 million ha, and $85 \%$ of this area is covered by Oxytenanthera abysinica, which is an indigenous bamboo to Ethiopia and endemic to tropical Africa. Bamboo is one of the fastest growing, highest productivity, most versatile, short harvesting cycle, and annually renewable and harvestable plant if it is managed in intelligent way. ${ }^{3}$

Bamboo is a highly utilized natural resource in many parts of the world. In Ethiopia the use of bamboo is limited to construction, fences and some rudimentary furniture and household utensils. Although bamboo is not an integral part of the Ethiopian economy, it plays a very important role socially, economically and ecologically in areas where it occurs naturally as well as where it is. ${ }^{4-6}$ Recently, bamboo has received increasing attention because of its easy propagation, vigorous regeneration, fast growth, high productivity and quick maturity.

It provides goods and services useful to mankind from birth to death. It is a source for food, fodder, furniture, building materials, industrial inputs, medical plants and fuel. It also plays a vital role in environmental amelioration, bio-diversity and soil conservation and waste purification..$^{4-8}$

According to the analysis of the production- to- consumption system of the bamboo sector in Ethiopia, the BGR has got 328211ha of land covered by bamboo; out of these 43383.125 ha found in Homosha wereda. If we use these resources contribute a lot to the region development. Among these well endowed natural resources of the Region, that play a significant role in the livelihood of the community is bamboo. However now a days the size of bamboo 
forests in the region has been shrinking due to human and natural influences.

It was pointed out that enormous hectares of lowland bamboo in the region are cleared for crop production purposes. ${ }^{9}$ BenishangulGumuz Regional Food Security Strategy Report (BGRFSSR) has also identified various factors, such as encroachment, forest fires, absence of secure land use policy, effects of agricultural expansion and intensive resettlement programs (BGRFSSR, 2004), land use changes, bamboo mass-flowering, and damage by bio deteriorating agents such as termites, beetles and fungi. ${ }^{8}$

In addition it was informed that there is no comprehensive research on bamboo, despite the fact that forestry research has been conducted in the country for the past 30 years, bamboo is still not considered as a research commodity in Ethiopia, lack of awareness about the multiple uses of bamboo is the basis for delay of actions on development, research and conservation interventions.

Problems related to depletion of bamboo forest for different uses arise because of attaching less priority to the resource. Their ecological requirements also need further investigation. Appropriate (cheap and effective) techniques and methods of propagation by seed and vegetative means must be identified and verified through welldefined bamboo research. ${ }^{10}$

In addition to human influence and natural factors, the lowland bamboo in BGR has been under high pressure due to lack of knowledge on resource use. In order to reversing this situation, a lot of efforts have been taken by the government sectors (institutional strength, issues designed on the development plan \& implemented, design important by lows $\&$ practiced), but still there is a study gap on how to manage and sustainably utilize lowland bamboo potential of the district as well as the region.

Although the mass flowering exacerbate the problem, according to ${ }^{11}$ assessment flowering in lowland bamboo seem to be more frequent It flowers every 30-35 years. Currently, mass flowering thereby mass death has reached over $85 \%$ of the estimated total 400,000 ha bamboo in the region. ${ }^{11}$ The early flowered areas regenerated and have formed bamboo forest, remarkable former bamboo land has been changed to other land use system. The remaining also is critically challenged by wild fire which is traditionally set as management of range lands in the region. So far, there is also no record of new regeneration under dead populations.

Accordingly, in order to use these vital resources of bamboo effectively in a sustainable way \& enabling to re-storing the missing parts on the case of mass flowering through effective management way, we need to know and evaluate current $\&$ reliable information on the statues of natural regeneration \& management practice trends at the community level to obtain solution for faced major constraints.

\section{Results}

\section{Stand structure of lowland bamboo (Oxytenthera abyssinica)}

Bamboo stand structure is mainly concerned with the number of plants per unit area and the age composition (age structure). These parameters are important aspects in investigating bamboo stand dynamics and yield. The number of plants under the three age-groups varies under the two management regimes and were statistically significant at $\mathrm{p}<0.05$. Moreover, Plant size and height also varies in the two sites assessed but were not statistically significant.

Stand density: Number of seedlings per hectare of protected site (252250) was significantly higher than that of open site (66750) (Table 1). Moreover similar trend was observed for the culms density which is $9185 \mathrm{ha}^{-1}$ for protected site and $3555 \mathrm{ha}^{-1}$ for open site. The species densities of culms in the two sites were significantly different (Oneway ANOVA, $\mathrm{p}<0.05$ ) (Table 1). This type of distribution indicates that the reserved site had the highest level of seedlings recruitment. The Density of bamboo culms Arema bamboo forest with $\mathrm{DBH} \geq 2 \mathrm{~cm}$ was 9185 stems per hectare.

Table 1 Analysis of Variance (ANOVA) indicating significant differences in the regeneration potential of the two sites, in Jima and Sherkole Kebeles of Homosha District

\begin{tabular}{|c|c|c|c|c|c|c|}
\hline Variables & & Sum of squares & df & Mean square & $\mathbf{F}$ & $P$. \\
\hline Seedlings density (Protected) & Between Groups & 39544.58 & 1 & 1581.783 & 5.368 & 0 \\
\hline Culms density (Open) & Between Groups & 90.35 & 1 & 4.755 & 1.195 & 0.0257 \\
\hline Culms density (Protected) & Between Groups & 119.144 & 1 & 9.929 & 0.908 & 0.013 \\
\hline
\end{tabular}

Age structure: In general, from age structure data of the two sites, present study showed large variation in density of lowland bamboo in the two areas in each age classes, as follows: $\leq 1$ year old ( 4225 culms/ ha ), 1-2 years old (4960 culms/ha), and over 3 years old ( 0 culms/ ha) (Table 2). The age structure of bamboo showed that about 42 $\%$ (4960culms ha $^{-1}$ ) belongs to 1-3 years age class followed by 34 $\%\left(4225 \mathrm{culms} \mathrm{ha}^{-1}\right)$ of the stand below one years of age and none was recorded in above three years age category (Table 3 ). The ratio 1.5:1 age structure shows that the stand is at good age structure and well managed. The number of seedlings in protected area $(252250$ seedlings $\left.\mathrm{ha}^{-1}\right)$ was significantly higher than that of open site $(66750$ seedlings $\mathrm{ha}^{-1}$ ) (The species densities of seedlings in the two sites were significantly different (One-way ANOVA, p<0.05) (Annex 4).
Moreover, the contribution of culms between the ages of 1-3 years towards total standing stock was $76.5 \%$. Harvesting was observed to be related with culms size rather than age class across the management systems.

Harvesting was observed to be related with culm size rather than age class across the management systems (Figure 1). Average diameter of standing culms was $3.15 \mathrm{~cm}$, while it was $4.1 \mathrm{~cm}$ for cut stump this indicates that culms with larger size are usually harvested for construction purposes in their third or fourth year and younger ones for preparation of rope and crafts (Figure 1). Standing and cut culms size distribution was recognized to be statistically significant for open sites $(\mathrm{t}=2.12, \mathrm{df}=10, \mathrm{p}<0.1)$ (Table 2$)$. 
Growth characteristics: Both growth characteristics, namely Culm diameter at breast height (DBH) and Culm height showed different results among the studied areas. Higher DBH values were obtained from protected area $(3.10 \mathrm{~cm})$, and smaller from open site (Table 4). Similar trend was observed for height with values 4.50 and 3.80 , for protected and open areas respectively. Diameter and height of the culms per plots studied was statistically significant for open sites $(\mathrm{t}=2.831, \mathrm{df}=10, \mathrm{p}<0.05)$ (Table 4) (Appendix 4) (Figure 2).

Table 2 The size class of standing and cut culms in the two sites studied

\begin{tabular}{llll}
\hline & \multicolumn{3}{l}{$\begin{array}{l}\mathbf{9 0 \%} \text { confidence interval of the } \\
\text { difference }\end{array}$} \\
\cline { 2 - 4 } & $\mathbf{t}$ & df & Sig. (2-tailed) \\
\hline $\begin{array}{l}\text { Culms DBH protected - Cut } \\
\text { Culms DBH Protected }\end{array}$ & -0.409 & 19 & $.687^{*}$ \\
$\begin{array}{l}\text { Culms DBH open - Cut } \\
\text { Culms DBH Open }\end{array}$ & -2.122 & 10 & $.060^{* *}$ \\
\hline
\end{tabular}

“** significant *insignificant”

Table 3 Number of plants per hectare of the three age- groups under different management regimes $(n=31$, mean \pm SE)

\begin{tabular}{llll}
\hline Scale & Items compared & N & $\begin{array}{l}\text { Mean number of } \\
\text { culms } / \mathbf{h a}\end{array}$ \\
\hline $\begin{array}{lll}\text { Age group } \\
\text { protected }\end{array}$ & 1-3 Year & 20 & $4225 \pm 406$ \\
& $>3$ year & 20 & $4960 \pm 710$ \\
& $<$ year & 20 & $0 \pm 0$ \\
Age group open & 1-3 Year & 11 & $1409 \pm 858$ \\
& $>3$ year & 11 & $2146 \pm 535$ \\
& Open & 11 & $0 \pm 0$ \\
Seedlings & Protected & 11 & $66750 \pm 2942$ \\
& 20 & $252250 \pm 3205$ \\
\hline
\end{tabular}

Table 4 Diameter and height of plants per plot of the two sites studied

\begin{tabular}{lllll}
\hline $\begin{array}{l}\text { Management } \\
\text { regimes }\end{array}$ & $\begin{array}{l}\text { Maximum } \\
\text { DBH }(\mathbf{c m})\end{array}$ & $\begin{array}{l}\text { Mean } \\
\text { DBH }(\mathbf{c m})\end{array}$ & $\begin{array}{l}\text { Maximum } \\
\text { height }(\mathbf{m})\end{array}$ & $\begin{array}{l}\text { Mean } \\
\text { height }(\mathbf{m})\end{array}$ \\
\hline Protected & $3.85 \pm 0.1$ & $3.10 \pm 0.1$ & $6.7 \pm 0.2$ & $4.50 \pm 0.28$ \\
Open & $3.1 \pm 0.1$ & $2.80 \pm 0.1$ & $5.8 \pm 0.3$ & $3.80 \pm 0.25$ \\
\hline
\end{tabular}

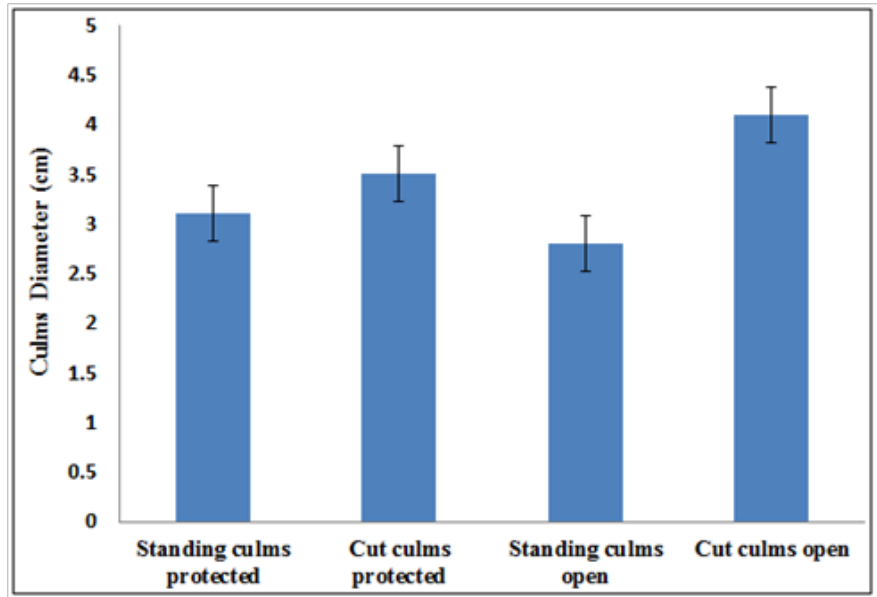

Figure 1 Average differences in culm diameter between standing and harvested culm in the two sites.

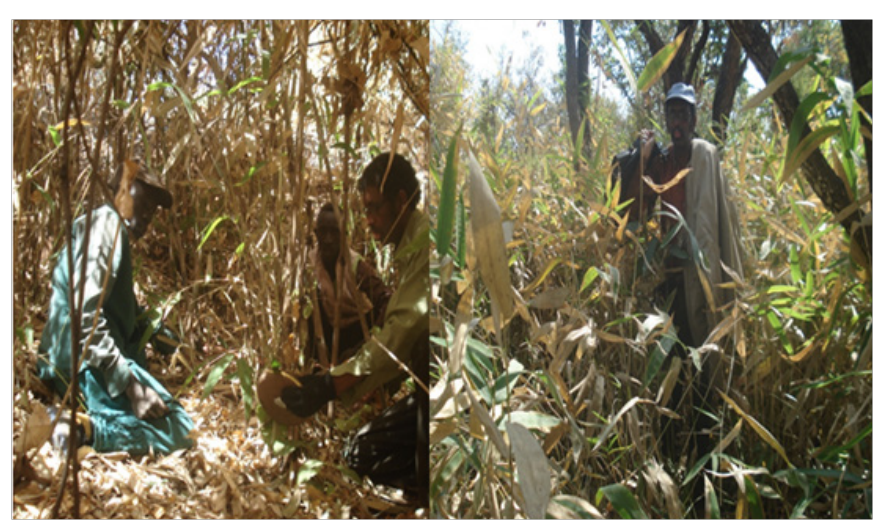

Figure 2 Field inventory activity at Jima Kebele/Arema Bamboo Forest.

\section{Demographic characteristics of households}

Farmers' settings in different household situations affect the perception and management of bamboo and its contribution to livelihoods. In this study, from the total of $80 \mathrm{HHs}$ interviewed $80 \%$ were male headed and the rest $20 \%$ were female headed (Table 5).

Table 5 Socio-demographic Characteristics of respondents in the study area $(\mathrm{N}=80)$

\begin{tabular}{|c|c|c|c|}
\hline $\begin{array}{l}\text { HH characteristics } \\
\text { Variable) }\end{array}$ & Parameter & Frequency & Percent \\
\hline \multirow{2}{*}{ Sex } & Male & 64 & 80 \\
\hline & Female & 16 & 20 \\
\hline \multirow{4}{*}{$\begin{array}{l}\text { Age of the } \\
\text { respondent }\end{array}$} & $18-30$ years & 13 & 16.3 \\
\hline & $31-45$ years & 34 & 42.5 \\
\hline & $46-60$ years & 27 & 33.8 \\
\hline & $>60$ years & 6 & 7.5 \\
\hline \multirow{3}{*}{ Occupation } & farmer & 72 & 90 \\
\hline & forest guard & 7 & 8.8 \\
\hline & merchant & 1 & 1.3 \\
\hline \multirow{4}{*}{$\begin{array}{l}\text { Household family } \\
\text { size }\end{array}$} & $1-5$ numbers & 21 & 26.3 \\
\hline & 6-10 numbers & 40 & 50 \\
\hline & $11-15$ numbers & 16 & 20 \\
\hline & $>15$ numbers & 3 & 3.8 \\
\hline \multirow{4}{*}{$\begin{array}{l}\text { Marital status of } \\
\text { Household }\end{array}$} & Married & 69 & 86.3 \\
\hline & Divorced & 3 & 3.8 \\
\hline & Widow & 7 & 8.8 \\
\hline & single & 1 & 1.3 \\
\hline \multirow{4}{*}{ Education Level } & Illiterate & 32 & 40 \\
\hline & Read and Write & 12 & 15 \\
\hline & Primary & 26 & 32.5 \\
\hline & Secondary & 10 & 12.5 \\
\hline \multirow{2}{*}{$\begin{array}{l}\text { Years lived in the } \\
\text { village }\end{array}$} & $>=30$ years & 76 & 95 \\
\hline & $>=5$ and $<30$ & 4 & 5 \\
\hline \multirow{4}{*}{$\begin{array}{l}\text { Role of household } \\
\text { head in the } \\
\text { community }\end{array}$} & Community member & 50 & 62.5 \\
\hline & community leader & 6 & 7.5 \\
\hline & religious leader & 3 & 3.8 \\
\hline & others & 21 & 26.3 \\
\hline
\end{tabular}


The average age of the respondent HHs was $43.175 y$ ears with ages ranging from 25 to 69 years. Of the total sample HHs those in the produce age class (18-45 years) comprise about $58.8 \%$. Regarding the marital status about $86.3 \%$ are married followed by $8.8 \%$ widowed and $3.8 \%$ divorced (Table 5 ). The average family size of the respondent HHs in the study area was 8 persons, with minimum and maximum of 2 and 69 respectively. The number of years the respondents has lived in the study area may affect knowledge about bamboo utilization, planting and its management. Thus in this study, the average number of years the households lived in the study area was ranges from 2 to 69 with average value of 51.7 years.

Education level of HHs may influence way of managing bamboo based livelihood practices or adoption of new technology. In terms of literacy level of the respondent HHs, about $40 \%$ were illiterate followed by those who have attended primary school (grade 1-6) $32.5 \%$ followed by those who are in read and write group (15\%) and only $12.5 \%$ have attended secondary school (grade7-12). With respect to the role of HHs in the community high proportion of households $(62.5 \%)$ has responded that they are involved in many development activities in their communities as community members.

The average family size of the respondent HHs in the study area was 8 persons, with minimum and maximum of 2 and 17 respectively. About $26.3 \% \mathrm{HH}$ respondents were in others category that is serving the community as leaders of women and youth representatives and social associations, $3.8 \%$ are religious leaders and $7.5 \%$ were community leaders. The respondents' livelihood/occupation has also an impact on the extent of bamboo resource utilization and its management. According to the data collected the majority of $\mathrm{HHs}$ interviewed were farmers $(90.0 \%)$ followed by forest guards $(8.8 \%)$ and Merchants (1.3\%).

\section{Farmers' knowledge on bamboo resources management, utilization and processing}

Farmers experience in bamboo stand management: In the study area bamboo stand managements like protecting bamboo forest from fire damage by making fire break, enriching the existing bamboo forest through afforestation, weeding, controlling illegal cutting through guarding were carried out. Accordingly, the survey results show that of all respondents $(21.25 \%)$ stated that protection from domestic animals and from illegal cutting by guarding the forested areas is the commonest management followed by making fire break $(18.8 \%)$, weeding $(5 \%)$ and afforestation (3.8\%). However, the other remaining $51.25 \%$ respondents were not involved in any of bamboo stand management activities (Table 6).

Table 6 Different bamboo management activities carried out by sample HHs $(\mathrm{N}=80)$

\begin{tabular}{lllll}
\hline \multirow{2}{*}{ Management activity } & \multicolumn{3}{l}{ Yes } & \multicolumn{3}{c}{ No } \\
\cline { 2 - 5 } & N & $\mathbf{\%}$ & $\mathbf{n}$ & $\mathbf{\%}$ \\
\hline Making fire break & 15 & 18.8 & 11 & 13.75 \\
Afforestation & 3 & 3.8 & 6 & 7.5 \\
Weeding & 4 & 5 & 16 & 20 \\
Protection (guarding) & 17 & 21.25 & 8 & 10 \\
Total & 39 & 48.85 & 41 & 51.25
\end{tabular}

Views related to the resource base indicated that there is a decreasing trend in this respect $(95 \%)$ due to agricultural land expansion, illegal cutting and mass flowering (32.5\%) followed by lack of conservation efforts, Wild fire and mass flowering (28\%). The remaining HHs pointed the combination of illegal cutting, wild fire, lack of conservation efforts and mass flowering have contribute also to the bamboo stock shrinkage observed so far (15\%) (Table 7).

Table 7 Existing farmers knowledge on bamboo resource status in the study area $(\mathrm{N}=80)$

\begin{tabular}{lll}
\hline & $\begin{array}{l}\text { Number of } \\
\text { responded HHs }\end{array}$ & Percent \\
\hline Trend of Bamboo forest & 76 & 95 \\
\hline $\begin{array}{l}\text { Depleting } \\
\text { Not depleting }\end{array}$ & 4 & 5 \\
\hline Causes for its depletion & & \\
\hline $\begin{array}{l}\text { Only mass flowering } \\
\begin{array}{l}\text { Agricultural land expansion, Illegal } \\
\text { cutting and mass flowering }\end{array}\end{array}$ & 26 & 8.8 \\
$\begin{array}{l}\text { Lack of conservation efforts, Wild fire } \\
\text { and mass flowering }\end{array}$ & 23 & 32.5 \\
$\begin{array}{l}\text { Illegal cutting, Wild fire, Lack of } \\
\text { conservation efforts and mass flowering }\end{array}$ & 12 & 28.8 \\
\hline
\end{tabular}

Farmers knowledge on bamboo resource ownership and legal status: In the study area the existence of lows governing forest utilization and management were not well recognized by the community. Even though there are task forces facilitating the protection of bamboo forests their practical activity in creating awareness and implementing the lows was very limited so far. Moreover, the sampled HHs responded that the owner of the forest nearby their kebele is under the administration of both the community and the government (Table 8).

Table 8 Respondents knowledge on bamboo resource ownership and legal status

\begin{tabular}{llll}
\hline $\begin{array}{l}\text { Owner of } \\
\text { bamboo forest }\end{array}$ & $\begin{array}{l}\text { Government34 } \\
(\mathbf{4 2 . 5 \% )}\end{array}$ & $\begin{array}{l}\text { Community 37 } \\
\mathbf{( 4 6 . 3 \% )}\end{array}$ & $\begin{array}{l}\text { Both 9 } \\
\mathbf{( 1 1 . 3 \% )}\end{array}$ \\
\hline $\begin{array}{l}\text { Forest governing } \\
\text { low }\end{array}$ & Yes 34(42.5)\% & No 46(57.5\%) & \\
$\begin{array}{l}\text { Low enforcing } \\
\text { body }\end{array}$ & Yes 71(88.8\%) & No 9(11.2\%) & \\
$\begin{array}{l}\text { Effectiveness of } \\
\text { low enforcement }\end{array}$ & V. good 5(7\%) & $\begin{array}{l}\text { Medium } \\
19(26.8 \%)\end{array}$ & $\begin{array}{l}\text { Poor } \\
47(66.2 \%)\end{array}$ \\
\hline
\end{tabular}

The consequences of overexploitation have direct effect on bamboo population status, Culm characteristic and regeneration potentiality (Table 8 ). When property rights to natural resources are absent and unenforced the result is free riding and over exploitation. Higher intensity of exploitation in a low productivity area can further affect the ecological and economic sustainability of the species and can lead to the elimination of the species from a given area (Figure 3).

Farmers' experience in bamboo growing/cultivation: The study has revealed that farmers in the study area have some experience in cultivating bamboo. Moreover, the farmers have largely gained the experience from NGOs followed Parents, friends, neighborhoods and government (Table 9).

Farmers' knowledge on season of bamboo planting is almost similar. With regard to the planting material, about $44.7 \%$ of the respondent households have got from NGO's support followed by 
personal collections from wild and some from government. Most of the households use seedlings donated by different bodies $(42.1 \%)$ followed by own collections from wildlings of about $50 \mathrm{~cm}$ long through offset method of propagation (23.7\%) and very few uses seed sowing (Table 9).

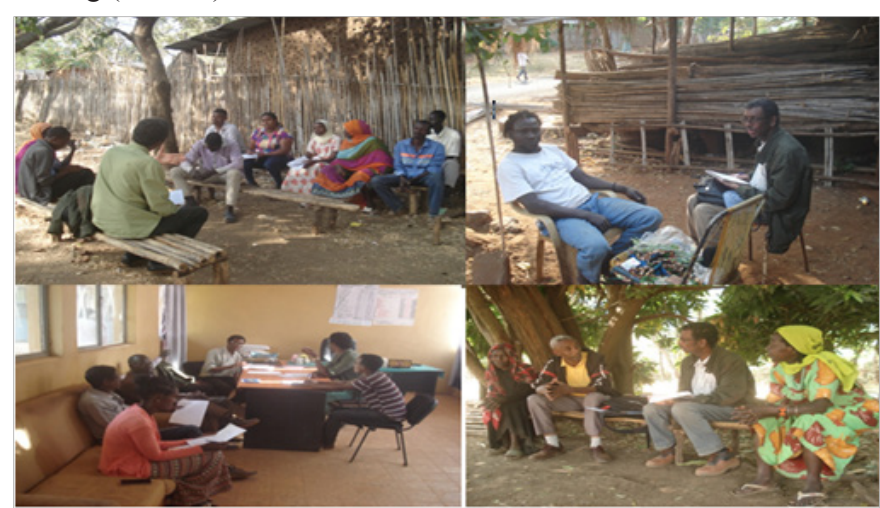

Figure 3 Focused group discussion (Left) and interviews (Right) with different stack holders.

Table 9 Practices and Sources of knowledge and skill for bamboo cultivation $(\mathrm{N}=80)$

\begin{tabular}{lllll}
\hline & \multicolumn{3}{c}{ Yes } & \multicolumn{2}{c}{ No } \\
\cline { 2 - 5 } & N & \% & n & \% \\
\hline Bamboo growing experience & 38 & 47.5 & 42 & 52.5 \\
\hline Sources of Experience for bamboo cultivation & & \\
\hline NGOs & 13 & 34.2 & - & - \\
Government & 10 & 26.3 & - & - \\
Parents, neighbor and friend & 15 & 39.5 & - & - \\
\hline Sources of planting material & & & & \\
\hline NGOs & 17 & 44.7 & - & - \\
From wild & 13 & 34.2 & & \\
Government & 8 & 21.1 & - & - \\
\hline Kind of planting materials used & & & & \\
\hline Seedlings & 16 & 42.1 & - & - \\
Seed sowing & 7 & 18.4 & - & - \\
Collections from wildlings & 9 & 23.7 & - & - \\
Seedlings and Seed sowing & 6 & 15.8 & - & - \\
\hline
\end{tabular}

\section{Utilization of bamboo resource}

This study revealed that the trend on bamboo harvesting and utilization by framers has been increasing during the last twelve years. Views related to utilization indicated that there is an increasing trend in this respect due to better access to roads and resource limitations resulting in more utilization particularly in areas were bamboo vigorously flowered and died (Table 10).

According to the households respond after mass flowering and death of bamboo most of the resources were massively exported to Sudan by merchants through collections by local farmers through the guidance of administrators at different levels. Until then the continuous and huge bamboo forests were now formed a patchy of bamboo forests through natural regeneration from seed and rhizome which is completely different from the bamboo resource stock present previously in the study area because of both the anthropogenic and other factors.

As a result local peoples of the study area were forced to search for the resource either from communal bamboo forest areas too far from the village or to collect from the regenerating bamboo stock nearby their village by any means $(43.8 \%)$. Moreover, the other villagers were forced to walk too far distances to collect the resources basic to their livelihood $(26.3 \%)$ followed by those either who can buy the resource from market or collect from the regenerating bamboo forest and this is mostly done by the HHs who can't go farther distances for bamboo resource collection $(16.3 \%)$.

The knowledge of bamboo harvesting season and stand age is important to get quality and better stand of bamboo Culm. About $56.2 \%$ of the respondents harvest their bamboo at any time/season as they need the resource and the remaining $43.8 \%$ harvest during the dry season. The farmers in the study area harvest bamboo at different ages. The majority of respondents $(67.5 \%)$ harvest bamboo culms at the age of less than one year and greater or equal to 3 year, about $25 \%$ greater or equal to the age 3 and few $(5 \%)$ harvest bamboo at all ages (Table 11). The majority of the respondents (75\%) confirmed that cutting matured at any time is applied in bamboo stands while the remaining (25\%) reported periodically selective harvesting.

The majority of HHs living in both Jimma and Sherkole kebeles (93.8\%) uses bamboo resource for construction only few households $(16.3 \%)$ sale bamboo in local market to generate income. However the remaining HHs use bamboo for fence $(58.8 \%)$, wood rope (23.8\%), making mate $(18.8 \%)$, export to Sudan $(21.3 \%)$, use for furniture making $(26.3 \%)$, feed directly the new shoots $(33.8 \%)$ and the remaining $20 \%$ responded bamboo as their animals feed (Figure 4) (Figure 5), (Appendix 4).

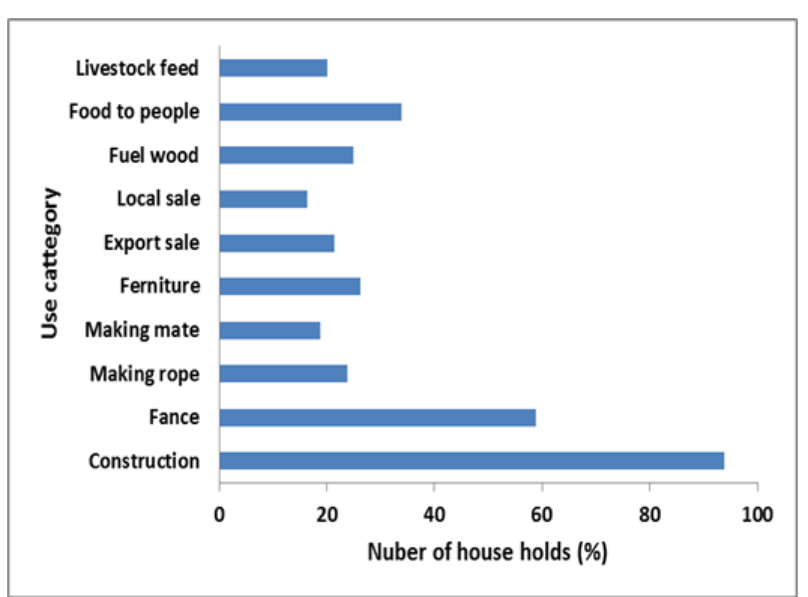

Figure 4 Use of bamboo resources by respondents

Note: * Total percent may exceed $100 \%$ due to multiple responses.

\section{Extension services on bamboo development, utilization and processing}

The provision of training on development, management and utilization of bamboo in the last five years (2012-2017) by government and nongovernment organizations was assessed. Accordingly, of the total respondent $\mathrm{HHs}$ only $21.3 \%$ received training on bamboo development, management and utilization (Figure 6). This training was given by NGOs $(16.3 \%)$, Government $(3.8 \%)$ and by both government \& NGOs (1\%). 


\section{The current threats to the regenerating bamboo population in the study area}

Despite the fact that some conservation practices were taking place in the two kebeles considered in the study surrounding the bamboo forests, the present study revealed several problems hindering the natural regeneration of lowland bamboo at Jima and Sherkole kebeles. Some of the most important problems were frequent and year to year fire occurrence, Conversion of previously bamboo areas in to agricultural land after mass flowering and death, continues harvesting of bamboo by people from refugees which may led the future regeneration unsuccessful and these accounted for $100 \%(\mathrm{n}=80)$ of all the respondents (Table 12). Other problem was associated with the collection of flowered bamboo for export to Sudan which accounts $95 \%(\mathrm{n}=80)$ (Figure 7$)$.

Table 10 Bamboo utilization trends during the last $5-12$ years in the study kebeles $(\mathrm{N}=80)$

Trend of resource base

\begin{tabular}{|c|c|c|c|c|c|c|}
\hline & & $\mathrm{n}$ & 73 & 0 & \multirow{3}{*}{\multicolumn{2}{|c|}{ Increased }} \\
\hline & \multirow[t]{2}{*}{ Increased } & & & & & \\
\hline & & $\%$ & 91.25 & 0 & & \\
\hline & & $\mathrm{n}$ & 7 & 78 & \multirow{3}{*}{\multicolumn{2}{|c|}{ Decreased }} \\
\hline & Decreased & & & & & \\
\hline & & $\%$ & 8.75 & 97.5 & & \\
\hline & \multirow[t]{2}{*}{ No change } & & & & \multirow{2}{*}{\multicolumn{2}{|c|}{ No change }} \\
\hline & & $\%$ & 0 & 2.5 & & \\
\hline The source of bamboo for HHs after mass flowering & HHS(n) & & & & & $(\%)$ \\
\hline From areas too far to the village & & & & & 21 & 26.3 \\
\hline From the regenerated $\&$ under aged one & & & & & 2 & 2.5 \\
\hline From areas too far to the village and From market & & & & & 2 & 2.5 \\
\hline $\begin{array}{l}\text { From areas too far to the village and From the regenerated \& } \\
\text { under aged one }\end{array}$ & & & & & 35 & 43.8 \\
\hline From market and From the regenerated \& under aged one & & & & & 13 & 16.3 \\
\hline
\end{tabular}

Table 11 Farmers knowledge on bamboo harvesting season and age of harvesting $(\mathrm{N}=80)$

\begin{tabular}{|c|c|c|c|c|}
\hline Knowledge on bamboo harvesting season and age & & Any time needed & & Dry season \\
\hline $\mathrm{N}$ & & 45 & & 35 \\
\hline$\%$ & & 56.2 & & 43.8 \\
\hline Harvesting age & 1-2 years & $\geq 3$ years & $<1 \& \geq 3$ years & All age category \\
\hline $\mathrm{n}$ & 2 & 20 & 54 & 4 \\
\hline$\%$ & 2.5 & 25 & 67.5 & 5 \\
\hline
\end{tabular}

Table 12 Constraints to naturally regeneration bamboo after gregarious flowering

\begin{tabular}{lll}
\hline Threats to regeneration of bamboo & Yes & No \\
\hline $\begin{array}{l}\text { Fire hazard } \\
\begin{array}{l}\text { Change in to agricultural land after } \\
\text { mass flowering }\end{array}\end{array}$ & $60(100 \%)$ & 0 \\
$\begin{array}{l}\text { Over harvesting by settlers (Refugees) } \\
\text { Massive harvesting of flowered \& }\end{array}$ & $80(100 \%)$ & 0 \\
$\begin{array}{l}\text { died bamboo for export to Sudan by } \\
\text { Merchant }\end{array}$ & $76(95 \%)$ & $4(5)$ \\
\hline
\end{tabular}

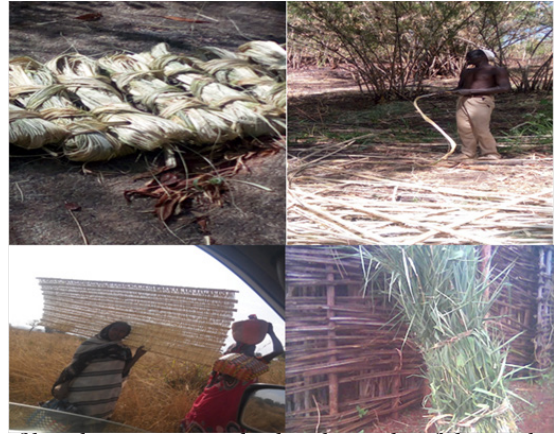

Figure 5 Use of bamboo resources by local people of the study sites. 


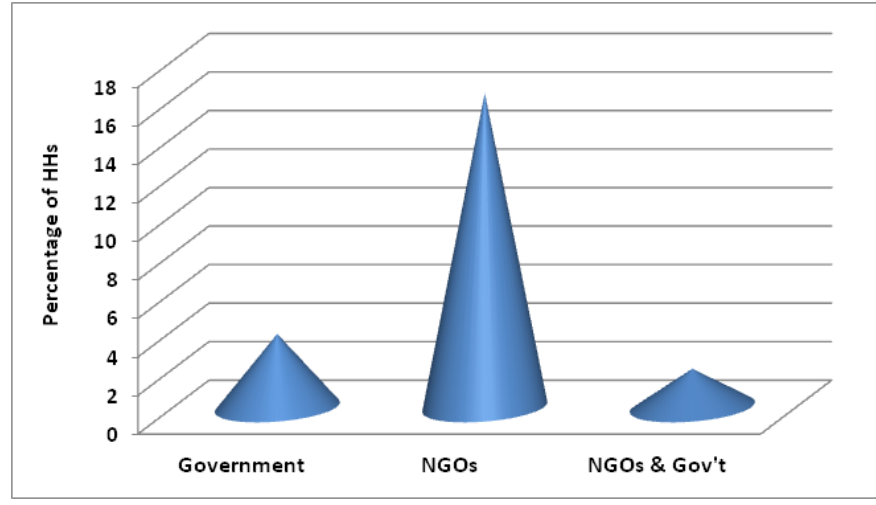

Figure 6 Farmers who received extension services and trainings on bamboo development, management, utilization and processing.

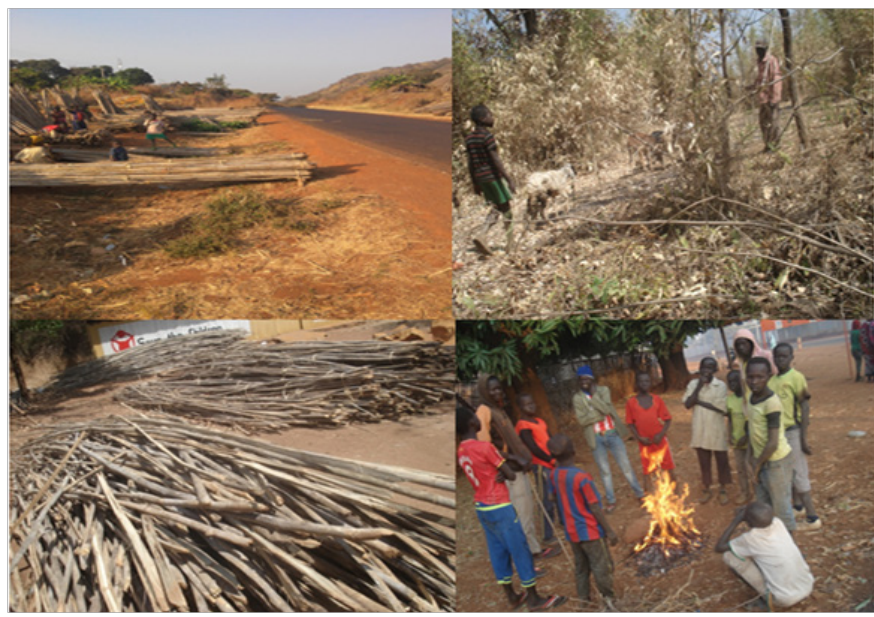

Figure 7 Disturbance of bamboo forest by refugees at Sherkole Kebele.

\section{Discussion}

Bamboo stand structure is mainly concerned with the number of plants per unit area (stand density) and the age composition (age structure) and the resulting parameters. ${ }^{12}$

Low seedlings density per hectare $\left(252,250 \mathrm{ha}^{-1}\right)$ in the reserved lowland bamboo forest at Jima kebele 'Arema Bmboo Forest' was manifested by low regeneration of lowland bamboo from seed germination and its establishment, and is affected by a suit of biotic and abiotic factors, including amounts of viable seeds produced during mass flowering and high disturbances which is much smaller than the seedling density by ${ }^{10}$ research report made in Sherkole Kebele (Homosha District), which informed that the density of germinating seedlings or wildlings of lowland bamboo within previously mass flowered and mass died stands was found to be as high as 6 seedlings per $50 \mathrm{~cm}^{2}\left(12,000,000\right.$ seedlings ha $\left.{ }^{-1}\right)$. To the contrary ${ }^{13}$ reported that the seedling density of bamboo in Anbesa Forest was 427.50 per ha. Likewise, comparable culm density with $\mathrm{DBH} \geq 2 \mathrm{~cm}$ in the protected area $\left(9185 \mathrm{culms} \mathrm{ha} \mathrm{h}^{-1}\right)$ implies the existence of a good potential for the restoration of bamboo communities. This is also supported by ${ }^{13}$ stating that the Density of bamboo culms in Anbessa forest with $\mathrm{DBH} \geq 2 \mathrm{~cm}$ was $12,458.56$ stems per ha. The density of both the culms and seedlings recorded was higher than the one recorded by ${ }^{10}$ and was also stated that under natural conditions, the number of culms per ha of lowland bamboo was reported to be only 8000 . However, plot level records indicate that plantations of this species can have at least
40,000 culms per ha which is much lower than the natural seedlings recorded in the study area. The differences observed may be due to much viable seed set because of mass flowering and age of the forest. Also the low proportion of seedling and culms density at open site $\left(66750 \mathrm{ha}^{-1} \& 4942 \mathrm{ha}^{-1}\right.$ respectively) indicates the impact of human and animal interference on their regeneration.

Stand density between the two sites varied markedly. The lowland bamboo stand structure of the study area (both protected and open) was mainly represented by $<1$ year and 1-2 year old culms. This is similar with the study by ${ }^{14}$ stating that smaller and thinner bamboo culms recruits up to third year of stand age reported in $O$. abyssinica. So immature culms, their small size can't yield the desired output of villagers and therefore not harvested at initial stage of stand development. A stable population structure with preponderance towards young aged culm is key for maintaining the stand productivity ${ }^{15}$ However, the size of culms is a main factor to indicate the stand condition, usually big bamboo can produce and accumulate more nutrients for stand growth because it occupies more space and absorbs more mineral elements. ${ }^{16}$

Growth performance of lowland bamboo culm is influenced by site productivity, disease, fire and management type. The overall mean height growth of bamboo at the study site (both open and protected) was $4.5 \mathrm{~m}$ and 3.8 respectively which is greater than $3.5 \mathrm{~m}$ at the age of two year reported by. ${ }^{10}$ It was also reported that the height of green culm for lowland bamboo ranged from 2 to $12 \mathrm{~m} .{ }^{9}$ The overall average diameter at breast height for both protected and open areas was $3.1 \mathrm{~cm}$ and $2.8 \mathrm{~cm}$. This result was slightly lower than values report by ${ }^{13}$ indicating an average values of $4.5 \mathrm{~cm}$, with range between 2.8 and $6.2 \mathrm{~cm}$. It is also slightly lower than values reported by ${ }^{10}$ indicating $3.5 \mathrm{~cm}$. This may be because the bamboo population of the study site is much younger that the rhizome is not well established to give new shoots that gives rise to larger culms. Analysis of data revealed a loss of $75 \%$ of the total stock in both open and protected sites was belongs to culms with bigger root collar diameter $(4.5 \mathrm{~cm})$ and none culms with the age greater than three year was recorded in the standing clump in both study sites. Culms of bigger diameter are usually harvested for construction purposes in their third or fourth year and younger ones of the some size for preparation of crafts. ${ }^{12,15}$

In the study area standard and scientific bamboo management practices such as mulching, application of manure, Selective thinning, and weeding etc... were minimal. However, there are sorts of cultural management practice recorded during an interview. According to the survey result of all respondents only $21.25 \%$ stated that protection from domestic animals and from illegal cutting by guarding were the common management practices they faced so far. This is in agreement with report of ${ }^{17}$ that indicated in Ethiopia, there is no management practice for government owned natural lowland bamboo stands. No protection what so ever from illegal harvesting, wildfire, pests and disease; no protection from encroachment and clear felling; no practical arrangements exist to manage, protect and utilize natural lowland bamboo forests.

According to the Forestry Conservation, Development and Utilization Proclamation No. 94/1994, two types of forest ownership are recognized in Ethiopia: forests that belong to the government (federal or regional) and private forests.

In the study area majority of the respondents know that bamboo forest in their area belongs to either the government or to the community. Whereas a very few respondents stated that the forest 
belongs to both the government and the community, but the existence of lows governing forest utilization and management were not well recognized by the community. This is in agreement with the report of ${ }^{6,17}$ indicated that the government owned bamboo forests are actually nobody's forests that have been suffering from the "tragedy of the commons" due to lack of awareness and limited low enforcements.

In the study area, there is a limited experience of bamboo cultivation. The observed bamboo plantations in the homesteads and agricultural farms were natural regeneration with some cultivation experiences from NGOs. This study concurs with the report by ${ }^{6}$ indicated that as a result of lack of value addition on bamboo resources farmers have been slow in promoting cultivation of indigenous bamboo. This is also supported by ${ }^{1} 8$ indicating that in western Ethiopia it was observed that most of the farmers have very few clumps (1-4 Clumps) of bamboo in their homesteads and they don't do any silvicultural operation in natural bamboo plantation. However, with the strong technical and financial support from NGOs, they have started bamboo plantation in the community forest in a small scale by the scientific method of cultivation.

In the study area bamboo is harvested for construction and fuel wood during the dry season. This is because in the dry season the starch content of bamboo culms will be less so that bamboo product will be less sensitive to insect and pest attack. This is also supported ${ }^{2}$ harvesting should be carried out during the dry season when the culm nutrient and starch content are the lowest with the aim to prevent culms being attacked by borers. In addition newly sprouting shoots will not be damaged when bamboo is harvested during this time. According to ${ }^{2}$ a good harvesting age for bamboo culms ranges from 2 to 3 years. To the contrary majority $(67.5 \%)$ of the households in the study area harvest bamboo culms every year at the age of $<1$ and $\geq$ 3 years depending on its use. Culms of the age of 3 and greater than 3 years were harvested for construction this is because bamboo can attain its maturity and better quality culms within this age class. But on the other hand people of the study area harvested bamboo at its young stage $(<1$ year) mainly for rope and hand crafting to some extent and the newly sprouting shoots for food. This idea agrees with the reports indicating that methods for sustainable harvest of plantation bamboo are available but for wild stand a sustainable harvesting technique requires to be worked out. According to ${ }^{3,5,11}$ culms are usually harvested for construction purposes in their third or fourth year and younger ones for preparation of crafts. This activity may damage the newly sprouting shoots and may hamper its regeneration. Almost majority of the respondents ( $75 \%$ ) selectively harvest young culms for rope and handcrafting, matured for construction, dead, diseased and malformed, for fuel wood and new shoots for human food, new leafs and branches for animal feed. This is also supported by ${ }^{9}$ in eastern Africa local people harvest bamboo year round specially when there is scarcity of food.

With regard to bamboo culms processing, there is very little experience at the study site though some of respondent household living close to refugees (Sherkole kebele) had better experience in processing bamboo in to different products such as shelf, mat, basket chair, beehive and tables etc.... This is because bamboo resource users close to the Sherkole refuge have got better training and material support to process bamboo culm in to different products from some NGOs and projects like World Vision (WV) and Natural Resource Development and Environment Protection (NRDEP). Bamboo culms were also sold to Sudan by merchants during mass flowering and death.
With regard to extension services such as training, material and technical support and advices about bamboo management, utilization and processing, less attention is given. However, a few farmers had got technical and material support from NGO and project link World Vision (WV) and Natural Resource Development and Environment Protection (NRDEP).

The contribution of bamboo to livelihood diversification is significant in the study site. Collection from wild and production of bamboo is one of the major means of income and livelihood of the local community. In addition to income generation, the community use bamboo for house construction, fencing, for making of different furniture and animal fodder and human food and contributes a lot for income and livelihood of the HHs. The trend of bamboo resource use and exploitation by local community has been increasing through time. However, to the contrary the resource base is getting narrower and narrower.

Despite the fact that some management practices were taking place in the two kebeles considered in the study surrounding the bamboo forests, the present study revealed several problems hindering the natural regeneration of lowland bamboo at Jima and Sherkole kebeles. Some of the most important problems were frequent and year to year fire occurrence, land use change after mass flowering and death by local people, continues harvesting of bamboo by people from refugees may led the future regeneration practices unsuccessful and these accounted for $100 \%(n=80)$ of all the respondents. This is supported by ${ }^{15,19}$ indicating that the newly regenerating young bamboo plants might be constrained by fire which is traditionally set as management of range lands particularly in Benishangual Gumuz region. Other problem was associated with the harvesting of dried bamboo during mass flowering for export to Sudan which accounts $95 \%(n=80)$. This agrees with the report of ${ }^{2,8}$ stated as clear cutting depresses the rate of recovery of bamboo after cutting. According to ${ }^{2,4}$ after the mass flowering and subsequent death of vast population of lowland bamboo in Benishangul-Gumuz regional state of Ethiopia, Metekel Zone, Mandura district, only few surviving patches in the area were left after new regeneration where the rest of the bamboo area has been converted to other land uses. Degradation and land conversion have resulted in a significant loss of bamboo forests and resources throughout Ethiopia. ${ }^{18}$

\section{Materials and methods}

\section{Location}

Benishangul-Gumuz National Regional State (BGNRS) is one of the nine regional states Established in 1995 by the new constitution of Ethiopia that created a federal system of Governance. The region is located in the western part of the country between $9^{\circ} 30^{\prime}-11^{\circ} 30^{\prime}$ latitude in the North and $34^{\circ} 20^{\prime}-36^{\circ} 30^{\prime}$ longitudes in the East. The regional capital, Asossa is located at a distance of $687 \mathrm{~km}$ away from the capital city of the country, Addis Ababa. The region has also international boundary with the Sudan and south Sudan in West, and it is bordered by Amhara Regional state in the East and North, Oromiya Regional state in the East and South East and Gambella Regional state in the South. ${ }^{20}$

The total land surface of the region is estimated to be 50,380 $\mathrm{km}^{2}{ }^{21}$ BGR is divided into 3 administrative zones and 20 'woderas'. Homosha Woreda is one of the 20 woredas located at a distance 36 $\mathrm{km}$ from Assosa capital city of the region with area of $708.42 \mathrm{~km}^{2}$ \& 
it is found in eastern parts of the Benishangul-Gumuz Region, which is bordered by Kurmuk in north west, Menge in the north east, and Assosa in south.

Jima kebele, which is agro-ecologically, classified as lowland (kola) is one of the study area, in Homosha Woreda. It is located on the asphalt road to Kurmuk Woreda at a distance of $10 \mathrm{Km}$ from the woreda town. The other kebele which was proposed for this study is, Shorkole Keble on the same direction of North West on asphalt road to Kurmuk Woreda at a distance of $15 \mathrm{~km}$ from Homosha town. Currently these two Kebles do not have aged Bamboo population due to mass flowering and death phenomenon (Figure 8).
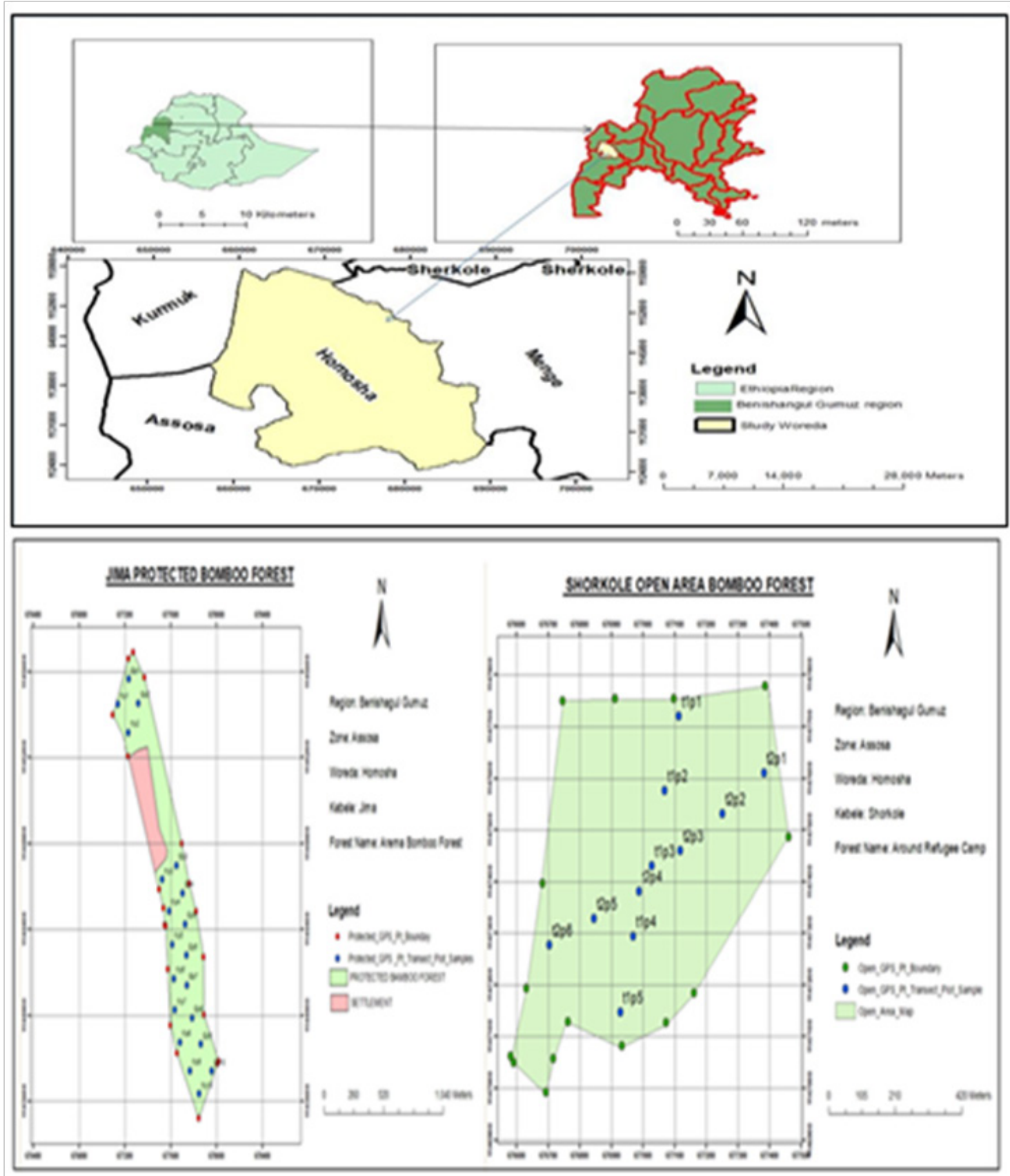

Figure 8 Location of study area, Homosha Woreda, Jima and Sherkole Kebeles.

\section{Climate}

According to the Assosa Metrological Service Agency the rainfall distribution pattern is mono-modal commencing towards end of April and ending in November with altitude ranging from 1100to 1350meters above sea level (m.a.s.1.), and the average rainfall ranges from $588-1,549 \mathrm{~mm}$ per annum. In the dry season, maximum daily temperature reaches to $21.4-31.5^{\circ} \mathrm{C}$, the hottest period is from February to April. The minimum temperature ranges, from $7.4-17.6^{\circ} \mathrm{c}$, depending on season and altitude (Figure 9). ${ }^{22}$ 


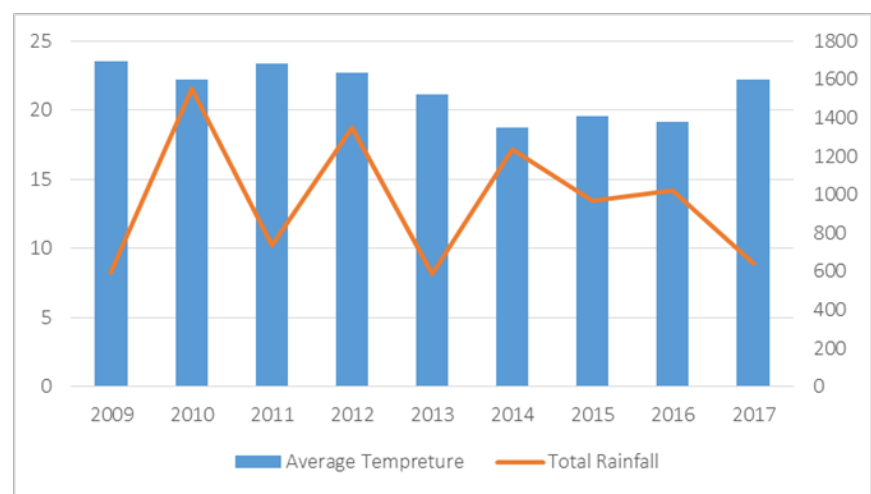

Figure 9 Climatic diagram showing average annual temperature and rainfall of Homosha District for 9 years. (2009-2017)

\section{Population}

Based on projected data, the current total population of the region is about 975,988 people in $2013 .{ }^{20}$ Currently, population density is sparse with a regional average of 15.91 people per square kilometer.
This woreda is not densely populated area in the region; it looks as it has high dispersed local /native people. Instead it has a number of refuge people around of the study area due to its location for settlement of refugees', $11,661 .^{20}$

As information obtained from the Homosah woreda Agricultural office reported that the total population of Homosha woreda without the refugees' are 14,894 Male \& 14358 female total $29252 .{ }^{20}$ From these in the study areas Jima Kebele 146 house hold heads and with the total population of 722 of which 356 are males and the remaining 366 are females. In Shorkole Kebele there are 231 household heads and 3015 house members (of which 1415are males and the remaining 1600 are females). The to tal population of refugees in Sherkole Kebele accounts 11,661(Table 13) of which 6192 are males and 5469 are females.

\section{Soil and topography}

Soil is often defined as the outer, mostly unconsolidated, layer of the earth's crust ranging from a few centimeters to more than $3 \mathrm{~m}$ in thickness. It is further described as a natural body composed of a mixture of organic and mineral materials in which plants grow.

Table I 3 Total population of Sherkole Refugee community

\begin{tabular}{lllllll}
\hline Age group & Male & $\mathbf{\%}$ & Female & $\mathbf{\%}$ & Total & $\%$ \\
\hline $1-4$ & 1053 & $90.03 \%$ & 991 & $8.50 \%$ & 2,044 & $17.50 \%$ \\
$5-11$ & 1474 & $12.64 \%$ & 1384 & $11.87 \%$ & 2858 & $24.50 \%$ \\
$12-17$ & 968 & $8.30 \%$ & 873 & $7.49 \%$ & 1841 & $15.80 \%$ \\
$18-59$ & 2594 & $22.25 \%$ & 2122 & $18.20 \%$ & 4716 & $40.40 \%$ \\
60 and $>$ & 105 & $0.88 \%$ & 99 & $0.85 \%$ & 202 & $1.70 \%$ \\
Total & 6192 & $53.10 \%$ & 5469 & $46.90 \%$ & 11,661 & $100 \%$ \\
\hline
\end{tabular}

Source: UNHCR, 2017

The soil of the study area is deep reddish, brown sandy clay loam with PH 5.5. The organic matter percentage is about 3.18\%. ${ }^{20}$ The larger area of the woreda has a diversified topography such as deep gorges with very steep slopes, very steep mountain ranges, and valleys and flat to almost flat low land plains..$^{21}$

\section{Land use and vegetation}

Despite of the rugged terrain, the cover type of this area is almost all under natural vegetation, mainly compressing of woody shrub grass land, shrub grass land, dense wood land, bamboo thicket, and open grass land.

In very few spots of the area along the valleys and plateaus, some cultivation is seen, where some settlement is there. The reason for low population pressure on these areas is because of unfavorable climatic conditions (high temperature and high humidity), tsetse fly infestation and malaria problems. ${ }^{21}$ The vegetation of the region can be classified in to eight-vegetation type. Those are dense forest, riverine forest, broad leaved deciduous wood lands, acacia wood land, bush land, shrub lands, Boswellia papyrifera wood land and bamboo thickets. ${ }^{20}$

\section{Socio economic condition}

According to 1994 population \& housing census, about $56 \%$ of the population was economically active. The major economic sector of the region is agriculture from which $70.31 \%$ of the income is generated. Compared to others, the unemployment rate is low (0.69) especially, in the rural areas (0.3). The government gave emphasis to the community participation and mobilization to enhance productivity both in rural $\&$ urban areas. ${ }^{21}$

\section{Materials used}

Materials like, measuring tape for measuring distance, plot size, and measuring the circumference of the clump, Hand compass for direction measurement (reading bearings), Diameter tape for collar diameter measurement, graduate measuring stick for measuring height, GPS (S62) for locating sample plots/ground reference, measurement of distance, and altitude, photo camera for image data collection, and other instruments like Riven, rope,data collecting formats, writing pad; sheet of papers and pen were used and all primary data from field inventory \& from $\mathrm{HH}$ respondents were collected.

\section{Research methods}

Data source: For the purpose of this research both primary and secondary data has been used to accomplish the desired objective. Primary data was collected using household survey, formal (focus group discussion), and informal discussion, field inventory of bamboo regeneration stands, and Secondary data was also used to supplement the information obtained from the primary sources like; thesis inputs, books, journals, census record, literature review, research article and Report results were used. 


\section{Sample size \& sampling determination}

Field observation: Before the actual research work and data collection, a reconnaissance survey was conducted to have a general overview of the research sites. Direct field observation to see how the prospective area is suitable to this study (geographic features), that helps to determine lay out and number of transect lines, sample sizes and possibly the study sites in different management system. Participant observation was also another method used in this study. This involves direct observation in the field during the survey period and households data collection.

Sampling techniques: The study was carried out at Homosha district by which composite an inventory assessment to see the density of natural regeneration of LLB after mass flowering and HHH survey activities for the management, utilization and institutional support practices of trends, a total of Eight bamboo growing kebeles have been categorized from the study district based on the information of natural resources development experts at woreda levels. And selected two representative Keble's purposely, due to their accessibility for transport, due to their location near to each other /adjacent enabling to comparison \& as other kebles, which have missed their original stand cover of bamboo areas at the same time on the case of gregarious flowering and were compared a regeneration status of the areas to understand management practices.

These respectively selected kebeles are Jima kebele which has bamboo areas relatively protected, the local people keeps it as protected area with no intervention of people and domestic animals, that they make a suitable condition for possible to restore the natural cover by its natural regeneration and the other keble which I have selected for my study was Shorkole which has bamboo areas after flowering is severely disturbed due to more interference of refugees' for different activities \& their home animals, these local people who lives around this keble have not have taken care \& makes a suitable condition for the land of bamboo areas after gregarious flowering enabling to bring back the natural cover on normal natural regeneration.

Consequently to see this assessment, two areas of the study were identifie as comparatively (site with good management and Open site) on bamboo regeneration status, a Systematic Sampling design technique were applied according to their density and objective of the study, a total of 31 sample plots were set up for this Inventory activities, that is 20 samples from Jima protected area of bamboo (50.79ha.) and again 11 samples from shorkole open / non managed area of bamboo (43.83 ha.).

Parallel line transects were laid out from North to south for the protected area as its topographical shape of the land and based on the area coverage and this was $140 \mathrm{~m}$ distance apart from one another in left and right. The other open forest has an oval shape \& used a cross transect line to accumulate representative data.

Along each transect line $10 \mathrm{mx} 10 \mathrm{~m}\left(100 \mathrm{~m}^{2}\right)$ sample quadrates were plotted for the protected site systematically at $150 \mathrm{~m}$ distance from one plot to the other interval and four sub plots $1 \mathrm{x} 1 \mathrm{~m}\left(1 \mathrm{~m}^{2}\right)$ at corners were employed for count and record seedling. ${ }^{13}$

The field inventory was done on 50.79 hectare in Jima Kebele \& 43.83 hectare in Sherkole Kebele.

On the other hand sampling household survey have conducted to see the management \& utilization trends of the local community using a simple random sampling technique, within structured and semi structured questionnaires were developed and administered, Out of the total 377 house hold heads living in these two Kebles of study area, 80 sample size of the $\mathrm{HHH}$ were determined using simplified formula

$$
\begin{aligned}
& n=\frac{N}{1+N(e)^{2}} \ldots \ldots \ldots \ldots \ldots \ldots \ldots \ldots \ldots \ldots \ldots \ldots \ldots \ldots \ldots \ldots \ldots \ldots \\
& n=\text { sample size for the research use } \\
& N=\text { total number of HHs living in these two Keble of study area } \\
& e=\text { margin of errors at } 5-10 \%
\end{aligned}
$$

Further to this, formal pilot tests were carried out for a questionnaire format filling up on 15 households to check the ease with which respondents react to the questions, to make sure that the questions are relevant and easily understood by the interviewee. Also for those data collectors and participants of the inventory one days orientation was given to enable them understand the questions and to provide them skill on how to approach individual households during the interview, how communicate each other on the field work and inventory technical activities, as well it was important to estimate the time it required for achievement.

All steps of these activities within the study area were done with the consulting of the head of the kebele and the rural development agents at the kebles. In addition to these experts (skilled personnel) from responsible governmental organization were admitted to participate on inventory activities $\&$ to fill the questionnaires by the HHs and to assess the technical process. A continuous close supervision of the researcher were a main duty and the researcher was fully participated in all part of data collection activities. Finally formal questionnaires survey sheets from the households nominators and data of field inventory was checked and collected from each study kebeles and was made ready for analysis.

\section{Data collection}

Focus group discussions (FGD): Focus group discussion was held to supplement and confirm information that was generated in the household questionnaire and in-depth interviews with knowledgeable peoples. In the study two kebeles and the expertise of the woreda a total of three focus group discussions with (8-10) focus group members involved were made in separate groups. These includes kebele representatives from youth, Religion leaders, administrators of the kebele, extension workers \& other known people who are accepted by the community and bamboo planters having good knowledge of their locality and natural resources were used for discussion.

The issues addressed in the focus group discussion interview are indicated in Appendix 1(Part I, II, \& III respectively). Moreover, informal discussion were also held at the regional office, including department Representatives of the Environment Forest \& climate change, Agriculture \& Rural Development, Extension, Biodiversity, Water shad management \& natural resource experts and NGOs representatives to generate more reliable information.

Households interview: The sampling of households was based on the selection of Kebeles in the vicinity of the lowland bamboo forest, road access and their livelihood base to the bamboo resources, and two Kebeles qualified for such criterion. And to achieve the objectives of the study, Household survey was taken through structured \& semi structured questionnaires for collecting quantitative and qualitative data, as the composition of the population of the proposed study 
area is homogenous who have the same ethnic and cultural practice, simple random sampling techniques was employed using the village registers, this type of sampling minimizes selection bias by giving all individuals an equal chance to be chosen, it is better comparatively to get more accurate data and it is important to get representative of the population under consideration. Out of the total house hold heads living in these two Keble of study area, 80 representative house hold heads were selected, proportionally in each Kebele (Jima 31HHs \& Shorkole 49HHs).

Bamboo regeneration inventory: In sampling for bamboo regeneration data, a parallel and a cross transect line method were used to achieve a systematic distribution of sample plots. After 4 transects and a total of 31 rectangular plots were laid out to census regeneration (20 samples from the protected bamboo forest/Jima Kebele/Arema Bamboo Forest/ \& 11 samples from the open one/from Shorkole Kebele), and the following Parameters have recorded for farther analysis (Figure 10).
Within the four corners, all seedlings were assessed to know their regeneration potential; Since the growth stock were expected as seedling vegetative phase (Yigardu et al.) ${ }^{10}$ in each plots $(10 \mathrm{~m} *$ $10 \mathrm{~m})$ matured bamboo plants $/$ Culm collar diameters at $5 \mathrm{~cm}$ above the ground (CD) for estimating size \& its density, and also measured their heights \& clump size (circumference) to assess the growth characteristics \& to see stand structure and also identified, estimated $\&$ categorized age of the stands to compare the sites scientifically through these all parameters. However, to analyze the size distribution of lowland bamboo forest under study the Root Collar Diameter (RCD) that was measured during the inventory was converted in to DBH by diameter conversion model ${ }^{23}$ to see if the size distribution of lowland bamboo of the area meets the standard $(2.5 \mathrm{~cm})$ stated by. ${ }^{13}$

The age determination of bamboo for each plot were differentiate by asking the community experiences and based on $^{24}$ criteria using internodes color, internodes, epiphytes, Culm sheaths, sheath ring at node, and branches (Table 14).

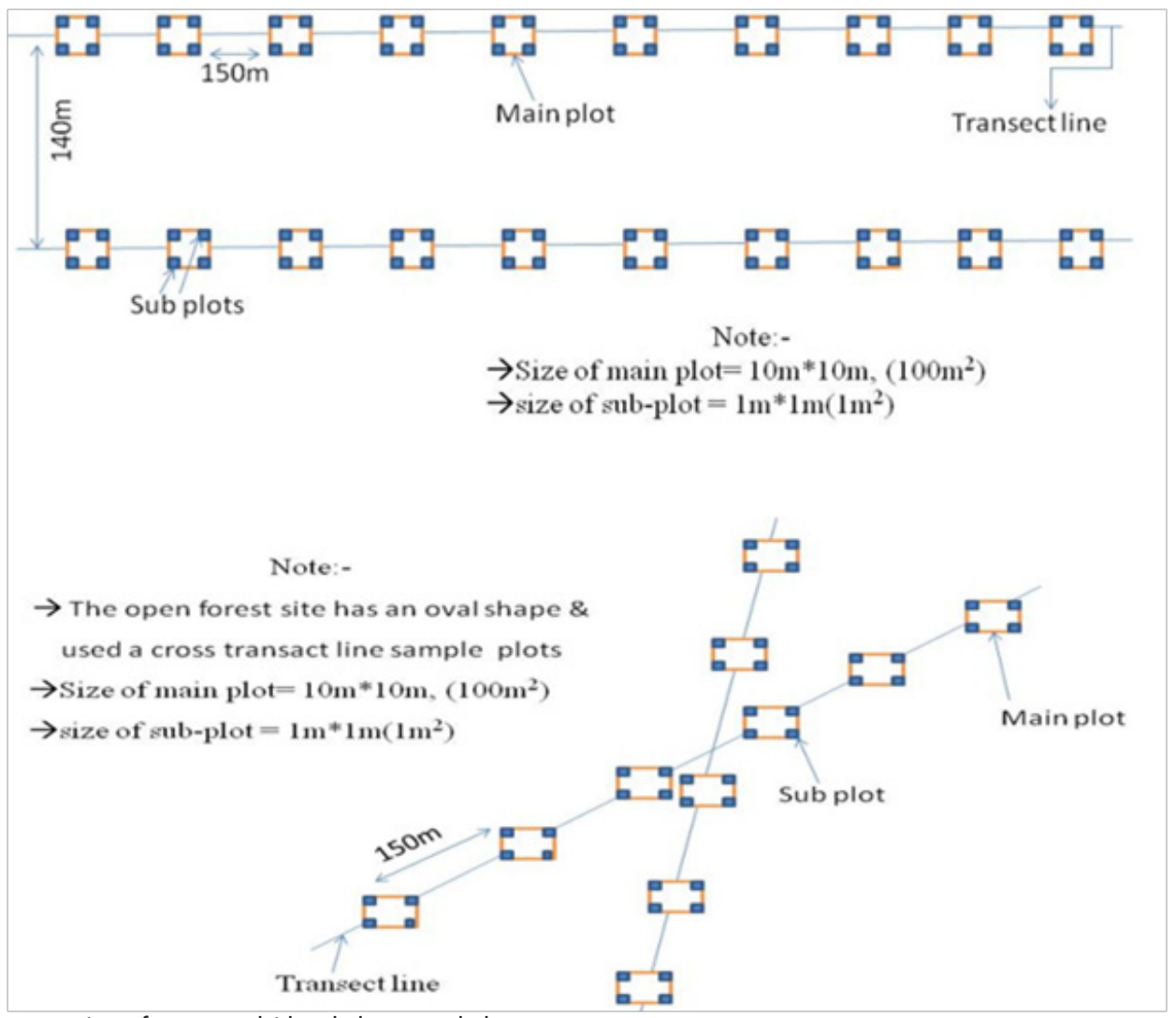

Figure 10 Schematic presentation of transects laid and plots sampled.

\section{Data analysis}

Data which were recorded from the transect survey were sorted and organized in to tables with the diameter at breast height, heights, age group and number of seedlings as variables. These variables were tested across the two management regimes (protected and open) using one-way Analysis of Variance (ANOVA). The stem densities at various diameter classes were tailed and analyzed by t-test to determine the bamboo population size class distribution. The regeneration potential was calculated by using the formula: Seedling Density/ha=No of plot counts/plot area $\times 10,000$. The resulting data were processed by SPSS statistical software Version 21 for comparison.

Before the questionnaires were entered in to appropriate statistical packages, they were edited and coded and the variables analyzed were the backgrounds of the respondents, in terms of frequency distribution, percentages, measure of central tendency, compare the behavior of various demographic categories (age, education gender, etc) in relation to use and management of lowland bamboo. Generally analysis for questionnaire was mainly descriptive as percentage, frequency, and table and associated graphs used in the interpretation of the results. ${ }^{25-28}$ 
Table I 4 Criteria used for bamboo culm age determination

\begin{tabular}{|c|c|c|c|}
\hline \multirow{2}{*}{ Diagnostic feature } & \multicolumn{3}{|l|}{ Age of plant } \\
\hline & $<1$ year & 1-3 years & $>3$ years \\
\hline Internode color & light green & gets yellowish or darker & yellow, dusty or dark depending on landrace \\
\hline Internode cover & Covered with white flour & Flour is falling off & No flour left \\
\hline Internode epiphytes & No internode epiphytes & Has lichen and epiphytes & Has lichen and epiphytes \\
\hline Culm sheaths & All or part of the culm sheath kept & Begin to fall off until none are left & No culm sheath remaining \\
\hline Sheath ring & Whole sheath ring or part of it kept & Remaining sheath ring gets harder & No culm sheath ring, it falls off \\
\hline Branches & $\begin{array}{l}\text { Light colored, not tough; no } \\
\text { secondary branches }\end{array}$ & $\begin{array}{l}\text { Existing branches feel soft, turning in } \\
\text { to yellow-green or dark after wards }\end{array}$ & Has secondary branches \\
\hline
\end{tabular}

Source: Ronald, p.(2005); Viet Ha Tran (2010).

\section{Conclusion}

From the preceding results and discussion of this study, it can be concluded that, stand density of the two sites varied markedly. Lack of protection and unregulated harvesting from villagers, merchants and people from refugees caused such drastic decline in stand density in open site at Sherkole kebele than the protected sit at Jima kebele /Arema Bamboo Forest. A stable population structure with preponderance towards young aged culms was observed in the protected site and this is a key for maintaining the stand productivity in the future.

Significant differences in total culms length and size of standing and cute culms have been observed between the two sites studied. Farmers living close to the refugees have better experiences of planting bamboo due to trainings, market access, increase in bamboo products and better knowledge and skill than the distant ones.

In the study area, there is a limited experience of bamboo management and cultivation. The observed bamboo plantations in the homesteads were natural regeneration with some cultivation experiences from NGOs. However, with the strong technical and financial support from NGOs, they have started bamboo plantation in the natural forest in a small scale by the scientific method of cultivation.

With regard to extension services such as training, material and technical support and advices about bamboo management, utilization and processing, less attention is given. However, a few farmers living close to the main road and Sherkole refugee camp had got technical and material support from NGO and project link with World Vision (WV) and Natural Resource Development and Environmental Protection (NRDEP).

The contribution of bamboo to livelihood diversification is significant in the study site. Collection from wild and production of bamboo is one of the major means of income and livelihood of the local community. In addition to income generation, the community use bamboo for house construction, fencing, for making of different furniture, music instruments, animal fodder and human food and contributes a lot for income and livelihood of the HHs. The trend of bamboo use by local community has been increasing through time but the resource base is getting depleted.

Despite the fact that some conservation practices were taking place in the two kebeles studied there are some important problems hindering natural regeneration of lowland bamboo. These includes frequent and year to year fire occurrence, land use change by both local farmers and investors after mass flowering and death, unresponsive harvesting of bamboo by people from nearby refugees and intensive harvesting of dead bamboo for export to Sudan by some merchants.

\section{Funding}

This research received no external funding.

\section{Acknowledgments}

The authors are grateful to the informants and local communities of Sherkole and Jima kebeles of Homosha district for sharing their incredible accumulated knowledge of bamboo. Without their contribution, this study would have been impossible. Authors are also thankful to forest officials of Forest Department of Homosha district for the support and encouragement provided during documentation of data about lowland bamboo.

\section{Conflicts of interest}

The authors declare that there is no conflict of interest regarding the publication of this article.

\section{References}

1. Akinlabi AG, Kwame AF, Akwada DR. Regeneration, Cultivation, and Sustenance of Bamboo. 2017:39-86.

2. Kibwage J, Netondo G, Odondo A, et al. Growth performance of bamboo in tobacco-growing regions in South Nyanza, Kenya. Afr $J$ Argic Res. 2008;3(10):716-724.

3. Fumaoyi. Cultivation and utilization on bamboos, chinese academy of forestry chinese academy of forestry chin. 1998.

4. Embaye K. Legal environment assessment and policy strategy suggestions, technical report. 2006.

5. Ensermu K, Tamrat B, Alemayehu G, et al. Socio-economic case study of bamboo sector in Ethiopia; an analysis of the production to consumption system. 2000.

6. Ensermu. A socio economic case study of the bamboo sector in Ethiopia an analysis. 2000 .

7. Ayer-smith. The use of Bambooas Cattle Feed. East Africa Agricultural and Forestry Journal. 1963;29(1):50-51.

8. Kassahun E. The Indigenous bamboo forest of Ethiopia; An overview, AMBIO. Journal Human Environment. 2000;29:518-521.

9. IMBAR. Study on utilization of lowland bamboo in benishangul gumuz region Ethiopia. 2010. 
10. Yigardu, Asabeneh, Zebene. Biology and Management of Indigenous Bamboo Species of Ethiopia. Ethiopia: Addis Ababa, 2016.

11. Sertse D, Disasa T, Bekele K, et al. Mass flowering and death of bamboo: a potential threat to biodiversity and livelihoods in Ethiopia. JBES. 2011;1(5):16-25.

12. Maoyi F, Jianghua X, Yiping L. Cultivation and Utilization of Bamboos. China: Research Institute of Subtropical Forestry; 2005. 137 p.

13. Tamene Yohanse. Plant diversity Carbon stock analysis along environmental gradient: the case of Anbesa Forest in Western Ethiopia. PHD dissertation, Ethiopia: AA Universty; 2016.

14. Banik RL. Morphological characters for culms age determination of different bamboos of Bangladesh. Bangladesh Journal of Forest Science. 1993;22(1/2):18-22.

15. Jaquith N. Bamboo Garden, 18900 NW Collins Road, North Plains 2017.

16. Yigardu Mulatu. Growth, morphology and biomass of arundinaria alpina (Highland Bamboo) (Poaceae) as affected by landrace, environment and silvicultural management in the Choke Mountain, Northwestern Ethiopia. Ph.D thesis, Addis Ababa University; 2012.

17. UNIDO. Bamboo market study in Ethiopia. Addis Ababa, Ethiopia: United Nation Industrial Development Organization; 2006.

18. Andargatchew A. Value Chain Analysis for Bamboo Originating from Shedem Keble, Bale Zone. MBA. Faculty of Business and Economics, Addis Ababa, Ethiopia: School of Graduate Studies, Addis Ababa University; 2008 .
19. Statz J, Degefa BA, Hierold J. Bamboo marketing for the Eastern Africa bamboo project Kenya and Ethiopia. Technical report to United Nations Industrial Development Organization (UNIDO); 2007. 95 p.

20. BOFED. Physical \& Socio-Economic Profile of Benishangul-Gumuz Regional State. 2017.

21. BIPPCSA. Facts about B/G, year-2; number-2. Assosa Ethiopia; 2000.

22. Ananta G. An Assessment of the Dependency of Farmers on Bamboo Resource for Rural Livelihood in western Ethiopia. 2008.

23. Chojnacky DC. Converting tree diameter measured at root collar to diameter at breast height. WJAF. 1999;14(1):14-16.

24. Yigardu, Asabeneh, Zebene. Biology and Management of Indigenous Bamboo Species of Ethiopia (BOFED, 2017). Physical \& SocioEconomic Profile of Benishangul-Gumuz Regional State. 2014.

25. EABP. Guidelines for cultivatoin ethiopian highland bamboo. Eas African; 2009. 45 p.

26. EABP. Guidelines for cultivatoin ethiopian highland bamboo. Eas African; 2009. 45 p.

27. Wong KM. Bamboo, the amazing grass. a guide to the diversity and study of Bamboos in south East Asia. Kuala Lumpur, Malaysia: IPGRI; 2004.

28. Yigardu Mulatu, Mengistie Kindu. Status of Bamboo Resource Development, Utilisation and Research in Ethiopia: a Review. 2010. 